\title{
Evaluating the effectiveness of guided versus non-guided interpretation in the Kruger National Park, South Africa
}

\begin{tabular}{|c|c|}
\hline \multicolumn{2}{|c|}{$\begin{array}{l}\text { Authors: } \\
\text { Mark Roberts }{ }^{1} \\
\text { Kevin Mearns }{ }^{2} \\
\text { Victoria Edwards }{ }^{3}\end{array}$} \\
\hline $\begin{array}{l}\text { Affiliations: } \\
{ }^{1} \text { School of Env } \\
\text { Design and M } \\
\text { University of P } \\
\text { United Kingdo }\end{array}$ & $\begin{array}{l}\text { ironmental } \\
\text { anagement, } \\
\text { ortsmouth, } \\
\text { m }\end{array}$ \\
\hline $\begin{array}{l}{ }^{2} \text { Department } \\
\text { Environmenta } \\
\text { University of S } \\
\text { South Africa }\end{array}$ & $\begin{array}{l}\text { I Sciences, } \\
\text { South Africa, }\end{array}$ \\
\hline $\begin{array}{l}{ }^{3} \text { School of Rea } \\
\text { Planning, Hen } \\
\text { School, Univer } \\
\text { Reading, Unite }\end{array}$ & $\begin{array}{l}\text { Estate and } \\
\text { ley Business } \\
\text { sity of } \\
\text { ed Kingdom }\end{array}$ \\
\hline $\begin{array}{l}\text { Corresponden } \\
\text { Kevin Mearns }\end{array}$ & ce to: \\
\hline $\begin{array}{l}\text { Email: } \\
\text { mearnkf@unis }\end{array}$ & sa.ac.za \\
\hline $\begin{array}{l}\text { Postal address } \\
\text { Private Bag X6 } \\
\text { South Africa }\end{array}$ & s: Florida 1710 \\
\hline $\begin{array}{l}\text { Dates: } \\
\text { Received: } 27 \\
\text { Accepted: } 06 \\
\text { Published: } 24\end{array}$ & $\begin{array}{l}\text { Mar. } 2013 \\
\text { Nov. } 2013 \\
\text { June } 2014\end{array}$ \\
\hline $\begin{array}{l}\text { How to cite th } \\
\text { Roberts, M., } \\
\text { K. \& Edwards, } \\
\text { 'Evaluating the } \\
\text { of guided vers } \\
\text { guided interpr } \\
\text { the Kruger Nat } \\
\text { South Africa', } \\
\text { Art. \#1160, } 8 \\
\text { dx.doi.org/10. } \\
\text { v56i2.1160 }\end{array}$ & $\begin{array}{l}\text { lis article: } \\
\text { Mearns, } \\
\text { V., 2014, } \\
\text { effectiveness } \\
\text { us non- } \\
\text { etation in } \\
\text { tional Park, } \\
\text { Koedoe 56(2), } \\
\text { oages. http:// } \\
4102 / \text { koedoe. }\end{array}$ \\
\hline $\begin{array}{l}\text { Copyright: } \\
\text { C 2014. The A } \\
\text { Licensee: AOS } \\
\text { OpenJournals. } \\
\text { is licensed unc } \\
\text { Creative Comr } \\
\text { Attribution Lic }\end{array}$ & $\begin{array}{l}\text { Authors. } \\
\text { IS } \\
\text { This work } \\
\text { der the } \\
\text { nons } \\
\text { ense. }\end{array}$ \\
\hline Read online: & $\begin{array}{l}\text { Scan this QR } \\
\text { code with your } \\
\text { smart phone or } \\
\text { mobile device } \\
\text { to read online. }\end{array}$ \\
\hline
\end{tabular}

In the face of growing pressure placed on the natural environment, the study on which this article is based considered the effectiveness of interpretive provision in mitigating the harmful effects of tourism on the environment. The aim of this research was to determine whether guided or non-guided interpretation is most effective in reaching the stated goals of interpretation. The four key goals of interpretation, namely visitor satisfaction, knowledge gain, attitude change and modification of behaviour intent, were used in the assessment of the relative effectiveness of guided and non-guided interpretation in the Kruger National Park, South Africa. Through comparing responses to questionnaires from post-visit samples and observing both guided and non-guided interpretation, the research found that guided interpretation was only marginally more effective in reaching the four key goals of interpretation than the non-guided interpretive media. Guided interpretation was found to be more effective in terms of visitor satisfaction, whilst guided and non-guided interpretation had only marginal differences in effectiveness in relation to knowledge gain, attitude change and intent to modify behaviour.

Conservation implications: The necessity of implementing an appropriate interpretation programme within protected areas cannot be overemphasised. The interpretation programme should be designed to include elements of both guided and non-guided interpretation in order to achieve a predetermined goal. The effectiveness of the programme should be evaluated periodically and amended where appropriate.

\section{Introduction}

The worldwide increase in tourism to natural areas has led to the notion that we are 'loving national parks to death' and this is becoming a major concern for national park managers (Vaske, Donnelly \& Whittaker 2000). The inherent fragile and unique nature of national parks and conservation areas suggests that they will be more severely affected by human activity (Weaver 2000). One of the most pressing problems of many national parks is how to cope with the growing number of visitors (World Tourism Organisation [WTO] 1992). An important measure of both the success and the sustainability of tourism in national parks and protected areas is the management of visitor impacts to ensure the long-term protection of the natural and cultural resources as well as continued visitor enjoyment and use (Marion \& Farrell 1998). Allowing visitor use makes impacts unavoidable; these impacts need to be managed. Visitor management in national parks seeks to redress this situation through the protection of natural and cultural resources and the provision of tourist activities and experiences. Without effective visitor management, tourism can lead to adverse impacts on the natural, cultural and heritage environments to the extent that they may also negatively affect visitor satisfaction (Shackley 1998). Effective interpretation can make a substantial contribution to improving the sustainability of tourism and, as a result, reduce the associated impacts from tourism (Moscardo 1996, 1998). Interpretation has already been recognised as no longer being a frill or a 'luxury' but an essential management function for every park or recreation area (Herbst 1979). Consequently, national park managers agree on the necessity to introduce interpretation programmes. The questions that arise for these managers within a constrained financial paradigm relate to the type of interpretation that should be implemented, as well as the effectiveness of the chosen type of interpretation. This research examined visitor perceptions in order to determine whether guided or non-guided interpretation is most effective in reaching predetermined goals of interpretation.

\section{Literature review}

Tourism is increasingly being seen as an important means through which the natural resources of national parks and conservation areas can generate revenues to ensure their long-term economic sustainability (Weaver 2000). Tourism growth to natural areas is now reaching levels where the impacts may be just as detrimental as other industrial sectors. Concern for the environmental 
consequences of tourism has grown since the 1990s (Buckley \& Pannell 1990; Hjalager 1996; WTO 1995). Interpretation has been recognised as an important solution to reduce these impacts whilst also educating the visitor to achieve the goals of sustainable tourism development (Ballantyne et al. 2007). Sustainable living and conservation have become hotly debated topics over recent years, with many commentators seeing social learning as a high priority on the environmental agenda. Through the concept of citizenship, it is thought that teaching in formal or informal settings might encourage and enable all members of society to contribute to the 'common good'. With the high visitor numbers recorded to nature reserves and national parks, it has been acknowledged that interpretation could aid development of environmental citizenship and, as a result, it is seen as an essential component of national park management.

Although there are numerous definitions of interpretation, they all centre on the idea of translating information from the scientist, the historian and the manager to the visitor or layperson (ed. McArthur 1998; Ward \& Wilkinson 2006). The most widely accepted definition of interpretation is that of Tilden (1977):

Interpretation is an educational activity which aims to reveal meaning and relationships through the use of original objects, by first-hand experience, and by illustrative media, rather than simply to communicate factual information. (p. 8)

As Tilden's definition suggests, interpretation is an approach to communicating which stresses the transfer of ideas and relationships rather than just facts and figures. This separates interpretation from conventional education. Since Tilden first published his work in 1977, many people and organisations have adopted their own interpretation or definition of 'interpretation'. The overarching theme of these definitions indicates that there is consensus that interpretation is a means of communicating visitor relationships with the environment, not just imparting scientific facts.

Environmental interpretation has been in existence for a long time. In 1919, the US National Park Service started to develop guided activities for visitors (Aldridge 1973). At the same time in South Africa, guides for visitors to national parks were being produced. The recent development of the interpretive philosophy and techniques has not just been related to natural areas, but has moved to include all aspects of heritage of a geographical area which are worth conserving for future generations. Interpretation is increasingly believed to play a role in influencing visitor beliefs, attitudes, knowledge and behaviours (Hughes \& Morrison-Saunders 2005; Kohl 2004; Kuo 2002; Moscardo 1998). Ham, Housego and Weiler (2005) suggest that when interpretation is carried out in protected areas, it is expected that it will encourage appropriate use, support responsible management and foster long-term conservation goals.

Ward and Wilkinson (2006) divide interpretation into two types, namely personal and non-personal. Wearing et al. (2007) concur with this notion and divide interpretation into two categories, (1) guided (e.g. guided walks) or (2) non-guided (e.g. boards) on the basis of delivery technique. Guided interpretive programmes are developed to utilise direct contact between the public and an interpreter or guide. Non-guided interpretive programmes are developed so that visitors do not have physical interaction or discourse with an interpreter or guide, but rather connect through different objects, media and resources. The investigation on which this article is based compared these two types of interpretation and their effectiveness.

Although there is no consensus on what successful or effective interpretation is, a number of authors have argued that interpretation should do one or more of the following, (1) enhance visitor experiences, (2) protect resources at sites, (3) protect visitors, (4) increase public support for an agency and its management policies, (5) add to or broaden visitors' perspectives about a place or idea and (6) enhance their knowledge and foster positive attitudes and behaviours with respect to the natural and cultural environment (Beck \& Cable 1998; Ham 1992; Ham \& Krumpe 1995; Ham et al. 2005; Knudson, Cable \& Beck 1995; Lewis 1980; Moscardo, Ballantyne \& Hughes 2006; Regnier, Gross \& Zimmerman 1994; Sharpe 1982; Ward \& Wilkinson 2006). As a result, the goals of interpretation are, (1) to satisfy visitors, (2) to instil knowledge gain, (3) to achieve attitude change and, consequently, (4) to achieve behavioural change (Hughes \& Morrison-Saunders 2005; Kohl 2004; Kuo 2002; Moscardo 1998). For the greatest achievement of all four goals, managers need to know how to deliver interpretation effectively. Lubbe (2003) argues that in South Africa there is a dire need for good interpretation, so that tourists 'will keep coming back'. Whilst what is communicated to tourists is important, the manner in which it is communicated is equally important (Lubbe 2003). The aim of this research was to compare the effectiveness of guided and non-guided interpretation in achieving the four stated goals of interpretation in the Kruger National Park (KNP) and to draw conclusions for a wider audience. The research analysed visitor perceptions after guided or non-guided interpretation experiences in relation to the stated goals of interpretation.

Uzzell (1998) contends that the evaluation of interpretation is recommended, but is rarely conducted. It is essential for managers to know if their chosen management tool is effective, thus preventing managers from spending scarce resources on tools that do not work (Brown, McCool \& Manfredo 1987; Gunderson et al. 2000). The most commonly evaluated outcomes of interpretation in research studies have been increased knowledge and attitude change, as they are generally easier to measure. Results of previous studies evaluating interpretation have left uncertainty over the effectiveness of interpretation - for this reason further research is necessary. Weiler and Smith (2009) state that there is an urgent need to develop strategies for assessing the effectiveness of interpretation programmes. This study attempted to aid in the development of a method for the assessment of the effectiveness of interpretation programmes in relation to the four goals of interpretation. 


\section{Visitor satisfaction}

Making recreational experiences more enjoyable is almost always a goal of interpretation (Knudson et al. 1995). Pearce and Moscardo (1998) found that interpretation at the Skyrail Rainforest Cableway near Cairns, Australia was positively linked to enhanced visitor satisfaction. In turn, Ham and Weiler (2000) found that five interpretive services in the Panama Canal protected areas contributed to overall tourist satisfaction. Interpretation must be enjoyable in order to hold visitors' attention (Ham 1992; Sharpe 1982). Although entertainment and satisfaction are not the only goals of interpretation they are important indicators of successful interpretation.

\section{Knowledge gain}

Interpretation can reveal a world many may not have seen before (Ham 1992; ed. Larsen 2003; Pastorelli 2003; Regnier et al. 1994; Ward \& Wilkinson 2006). Lee and Balchin (1995) suggest that in psychological terms the aim of interpretation is to achieve learning and, by helping visitors to better understand the idea of coexisting with the environment, their awareness of their place in the total environment may be enhanced (Sharpe 1982; Tisdell \& Wilson 2001). Phillips (1989) believes that the chief measure of interpretive effectiveness is whether information has been conveyed to the visitor. Orams (1996) concurs with this statement and further suggests that through increasing visitors' knowledge or understanding, interpretation could potentially prompt more environmentally responsible behaviour.

\section{Attitude change}

If interpretation succeeds in increasing visitors' understanding of the places they visit, it is hoped that it will lead to the respect for an area (Bramwell \& Lane 1993). Interpretation aims to broaden awareness and concern and to assist people in building relationships with, or understanding interrelationships between, what they are observing at the site and in their lives (ed. Larsen 2003; Lewis 1980). Iozzi (1989) argues that interpretation must include activities that are specifically designed to change the attitudes of the visitor.

\section{Behavioural change}

If interpretation is to be an effective technique in managing tourist-nature interaction and achieving sustainable development, it should do more than simply increase knowledge and understanding; it should prompt behaviour change (Moscardo 1996; Orams 1997). At a basic level, interpretation should seek to manage people's behaviour through the encouragement of their own personal development and self-realisation so that the way they behave is respectful of the potential impact their actions may have (Krippendorf 1987; Orams 1997). It is proposed that through interpretation, people will be encouraged to act in more appropriate ways (Ballantyne et al. 2007; O'Riordan, Shadrake \& Wood 1989; Stewart, Hayward \& Devlin 1998). Higham and Carr (2002) suggest that interpretation programmes may foster behavioural change relating to domestic lifestyle, which may contribute to the long-term benefit of the environment.

\section{Evaluation of interpretive programmes}

There have been a number of studies since the 1970s that have evaluated the influence of interpretation, with the large majority of these focusing on knowledge or attitude change amongst visitors. Some authors (McGehee \& Santos 2005; Russell \& Hodson 2002; Ryan, Hughes \& Hirgwin 2000) have highlighted the importance of evoking emotion as a means to encourage positive environmental behaviour amongst visitors. Munro, Morrison-Saunders and Hughes (2008) suggest that this may be difficult to achieve through textbased signs compared with interaction through a guide. Other authors (Mallick \& Driessen 2003; Orams 1996; Townsend 2003) have linked programme success with providing visitors with an opportunity to act upon newly formed attitudes and intentions. There is evidence that guided interpretation enhances the quality of the visitor experiences. Forestry Tasmania (1994), Hughes (1991), Moscardo (1998) and Schänzel and McIntosh (2000) linked success of interpretive programmes with guided communication. The evaluation of interpretive programmes is difficult for two main reasons. Firstly, there can be many ensuing experiences as a result of interpretation, such as inspiration and enjoyment, which cannot be measured by standard methodologies (Beckmann 1991). Secondly, interpretation takes place in recreational areas where many other aspects influence both visitors and interpretation: these influences can be difficult to control (McDonough 1986). In a literature study reviewing 21 articles that evaluated the outcomes of environmental interpretation programmes, Munro et al. (2008) found that about half of the studies had used post-experience sampling to evaluate interpretive influences on visitors. The Munro et al. (2008) study illustrates the spectrum of evaluation methods used in the field and that any attempt to apply a single evaluative process in environmental interpretation would probably favour certain methodologies.

Moscardo (1998) and Beaumont (2001) propose that research efforts to measure the effectiveness of interpretation can be put into two categories. The first is research that measures visitors' perceived satisfaction, knowledge gain, attitude and behavioural intentions (e.g. asking visitors to reflect on what they think they learned as a result of their experience). The second category includes research that aims to measure actual outcomes. Knowing how visitors feel when they come away from an experience is important as it provides a measure of the quality of the experience and visitors' satisfaction with their experience. This article follows the first approach.

There have been mixed results from studies that have evaluated the effectiveness of interpretation on influencing visitors' enjoyment, knowledge gain, attitude change and behavioural intentions. Some studies have found that interpretation has increased visitor enjoyment and knowledge, modified attitudes and increased behavioural intentions, whilst other studies have found that interpretation has had no effect. Munro et al. (2008) found that out of the 21 case studies reviewed, 19 considered the interpretive programme that was evaluated to be successful or at least partly successful. Guided experiences are generally accepted 
as the most effective form of interpretation, provided that it is well planned and implemented (Armstrong \& Weiler 2002; Beaumont 2001; Brody, Tomkiewicz \& Graves 2002; Ham 1992; Hughes \& Morrison-Saunders 2005; Luck 2003; Tubb 2003). However, an extensive review of the literature revealed that no direct comparison has been made between the relative effectiveness of guided and non-guided interpretation. This is supported by Weiler and Smith (2009), which confirms that there is a general lack of research on different interpretation techniques. The study that informed this article made a direct comparison between guided and non-guided interpretation in the KNP.

\section{Research method and design}

Moscardo (1998) and Beaumont (2001) separate interpretation evaluation into two categories, (1) visitor perceptions and (2) actual outcomes. The research reported in this article followed the first methodological approach, making visitor perceptions the focus of the study in evaluating the effectiveness of interpretive programmes. The research used a post-visit survey questionnaire to identify visitors' perceived outcomes of interpretation, assessed against the four main goals of interpretation, in order to evaluate the effectiveness of the two types of interpretation (30 guided and 30 non-guided questionnaires). Observations were also used to verify data collected in the survey responses and to add depth of understanding to the survey data (Kuo 2002; Novey \& Hall 2007; Tubb 2003).

The KNP was proclaimed in 1926; since then tourism has developed significantly and, in 2008, the Park already attracted in excess of one million visitors annually (Van der Merwe \& Saayman 2008). The KNP is located in the northeast of South Africa, bordering the Limpopo National Park of Mozambique. This research was conducted in 2010 in the Letaba Rest Camp in the KNP. Letaba is situated on the bend of the Letaba River, midway between the southern and northern boundaries of the KNP.

The guided interpretation evaluation was conducted after night drives that were undertaken in the company of trained field guides. Night tours last for two hours, during which the guides accompany up to 24 people whilst offering commentary on geographical sites and wildlife sightings. The non-guided interpretation was undertaken after visitors exited the Elephant Hall museum in Letaba, which covers elephant evolution, biology, behaviour, ecology and research. The Elephant Hall also showcases the ivory of eight of the KNP's greatest tuskers, including six of the 'magnificent seven'. This non-guided experience consists of several interpretive styles, which include both interactive and standard displays.

The visitor survey was designed in order to determine visitor satisfaction, perceived knowledge gain, attitude change and the visitor's intent to change their behaviour. Socio-demographic questions were also included in order to obtain a profile of the visitors participating in the study.
The questionnaire was designed to allow for comparison between guided and non-guided interpretation. This meant that the questionnaire was designed to be non-specific to site and interpretive media (Munro et al. 2008). The questionnaire used a combination of open-ended and closed-ended questions, as well as Likert scale questions. In the Likert scale questions respondents were shown a statement and were asked to indicate their level of agreement or disagreement with that statement with a ranking score of 1-5 (1 being 'strongly disagree', showing lower effectiveness levels; 2, 3 and 4 representing a continuum, until 5 being 'strongly agree', showing higher levels of effectiveness). These responses were used to determine the effectiveness of the different interpretation techniques in terms of the four goals of interpretation, namely visitor satisfaction, knowledge, attitude and behavioural intent. The survey was conducted on site at exit points of guided and non-guided interpretive settings. Data were collected from a self-administered questionnaire. The survey scope was explained to each respondent. The researchers also explained that the survey was anonymous and confidential. The questionnaire was then handed to any visitor over the age of eighteen. Visitors were asked to reflect on the experience they had just received and complete the questionnaire on site. The researchers were present to clarify any possible issues or concerns.

Observations were conducted as a secondary tool of research. As the actions and behaviour of people are a central aspect in this study, a natural and obvious technique is to watch what they do, record this information and then describe, analyse and interpret what has been observed. The researchers participated in the tours and the interpretive experience whilst observing visitors' actions, behaviours and interpretation participation, as well as assessing both guided and non-guided interpretation programmes. Observations were undertaken as discretely as possible to limit the intrusion on the guides and the visitors. Digital photographs were taken as a memory aid. Novey and Hall (2007) explains that by immersing themselves in the research setting and remaining anonymous, researchers can observe dimensions of visitors' behaviour, interactions and actions. Observations added a depth of understanding to data collected through the visitor survey.

\section{Results}

The discussion of the results follows the four goals of interpretation, namely, (1) visitor satisfaction, (2) knowledge gain, (3) attitude change and (4) intent to modify behaviour.

\section{Level of visitor satisfaction}

Guided interpretation in the KNP was found to be statistically more effective than the non-guided interpretive media at raising levels of satisfaction $\left(p=6 \times 10^{-5}, p<0.05\right)$. The overall average Likert-scale responses by the visitors in term of the series of statements in relation to visitor satisfaction was 4.09 for non-guided interpretation and 4.49 for guided interpretation, indicating that the visitor satisfaction levels were higher for the guided interpretation than the nonguided interpretation. 
Amongst the reasons given by respondents for their heightened satisfaction levels were, (1) the excellent knowledge of the guide, (2) the guide's personality, (3) seeing animals and (4) the ability of the guide to answer questions when asked. The guide was also considered to be very humorous and this seemed to hold the visitors' attention, drawing a good response from them. The visitors seemed to be very relaxed during the drive, joking and laughing with each other, which could reflect the guide's ability to act as a successful host. However, although guided interpretation was found to be more enjoyable, some reasons for dissatisfaction were given. For example, visitors noted that they were given the incorrect time for the tour departure and that the guide was sometimes difficult to understand because of a heavy accent and being softly spoken.

Reasons for satisfaction with the non-guided interpretation were given as information, elephant skulls and skeleton displays and the interpretive displays. For the non-guided interpretation, respondents indicated that they had enjoyed the interactive displays that were present at the Elephant Hall. This suggests that a large proportion of respondents enjoyed learning through interactive means. Interactive displays showing the heights of elephants compared to humans were very popular with visitors. Visitors were observed measuring themselves against elephant and human heights at various ages. Reasons for dissatisfaction in relation to non-guided interpretation by respondents indicated that there were not enough interactive displays and that many of the displays were old. The findings in relation to visitor satisfaction in this research concur with the findings of Moscardo (1998) and Schänzel and McIntosh (2000) that visitor satisfaction is higher in guided interpretation programmes.

\section{Level of knowledge gain}

The non-guided interpretive media at the KNP received a higher mean Likert-scale score for respondents' perceived knowledge gain (3.68), compared to 3.63 for guided interpretation; however, the difference was not found to be statistically significant ( $p=0.03, p>0.05)$. When asked to mention two things they had learnt as a result of the interpretation, over $80 \%$ of the guided tour respondents were able to give one or more specific details they had learnt compared to only $30 \%$ of those respondents who had attended the non-guided interpretation. This shows that those who had attended the guided interpretation in the KNP were able to recall facts passed on by the interpreter better than those who participated in the non-guided interpretation. The guide of the nightly game drives was able to hold the visitors' attention with anecdotes, enthusiasm and knowledge.

In contrast, the researchers noted that, on average, visitors spent between $20 \mathrm{~min}$ and $25 \mathrm{~min}$ in the Elephant Hall (nonguided interpretation). The researchers believe that it is not possible to read all the information on display in the Elephant Hall within that time scale. A time estimate for reading all the interpretive material in the Elephant Hall will be around $3 \mathrm{~h}$. The non-guided interpretation was unable to hold the visitors' attention for long periods of time, which has an impact on the knowledge gained by the visitor. Section signs within the Elephant Hall tell the visitor what they are about to read in the forthcoming section. This interpretation draws the visitor's eye in an effective manner. However, the majority of the interpretation on show in the Elephant Hall is not of recent design and has a great deal of information packed onto the displays, which means that there is a large amount for visitors to read and take in. Some of the displays are difficult to follow, as there is no obvious route to follow and display cases offer no natural flow to visitors. The small blocks of writing within the cases appeared to be unappealing to the visitors as observing people's behaviour revealed few people stopped to read about the contents of the display cases. The researchers also noted that the explanatory cards contained a great deal of writing. Large amounts of writing may affect the visitors' desire to read further, resulting in the possibility that the viewers ignore the signage completely. However, there seemed to be a greater perceived knowledge gain from non-guided interpretation amongst the respondents.

\section{Degree of attitude change}

Guided interpretation was found to be more effective at provoking attitude change amongst respondents, with an average Likert-scale score of 4.31 , compared to 4.29 for non-guided interpretation. However, the difference was not found to be statistically significant $(p=0.47, p>0.05)$. In terms of attitude change, guided and non-guided interpretation delivered similar results.

\section{Intent to modify behaviour}

Guided interpretation received a marginally higher mean score for respondents' intent to change behaviour (3.78) than that found for respondents of the non-guided interpretation (3.73). However, the difference was not found to be statistically significant $(p=0.48, p>0.05)$. Both groups of respondents had high levels of education and showed prior environmental commitment through membership of environmental organisations and completion of courses and training, which may have affected their behavioural intent. At the start of the nightly game drives in the KNP, the guide gives a safety and behaviour awareness talk before the game viewing vehicle leaves the camp. The guide explains that visitors should remain in the vehicle at all times, refrain from allowing any body parts to protrude from the vehicle and, for the safety of all visitors, they are advised to remain seated whilst the vehicle is in motion. The researcher noticed that on several occasions the third message was not adhered to as many guests chose to stand whilst the vehicle was in motion, which suggests that the introductory safety message was not effective in that respect. According to $\mathrm{Hu}$ and Wall (2012), tour guides play a critical role in striving towards sustainable tourism in national parks and protected areas. The intent to modify behaviour was very similar in guided and nonguided interpretation.

\section{Ethical considerations}

Ethical approval for undertaking the research was obtained through the University of Portsmouth, School of 
Environmental Design and Management ethics committee. The research was also conducted under the consent and approval of the South African National Parks Board Social Sciences Research Department Coordinator.

All the participants in the study took part voluntarily, after they were informed of the objectives of the study and the completion of an informed consent agreement. All participants were entitled to withdraw from the study at any point. The completed questionnaires were also completed anonymously and confidentially. The original completed questionnaires were scanned and digitally stored with password protection, after which the original questionnaires were destroyed. The password protection was also maintained through the data encoding and analysis phases of the research.

\section{Trustworthiness}

To ensure validity and reliability of responses with the survey technique, the questionnaire was pre-tested on five visitors exiting the Elephant Hall at Letaba Camp in the KNP. After the collection of the five pretested questionnaires, the results were briefly analysed in order to determine if the required research instrument would deliver the expected results. This was found to be the case. During the entire period during which the questionnaires were being completed, the researchers were available should additional clarity be sought by the participants.

\section{Discussion}

Using the above results, the average scores for all four goals of interpretation are listed in Table 1. The combined interpretation scores for the four goals of interpretation indicated that there is only a marginal difference in the effectiveness between guided (4.05) and non-guided (3.95) interpretation, the only really notable difference being in terms of visitor satisfaction, which is much higher in guided interpretation.

In order to further explore the effectiveness of the different interpretation methods, visitors were asked to indicate their preferences in terms of interpretation type. These results are discussed below.

\section{Visitor preference of interpretation type}

Firstly, $83 \%$ and $87 \%$ of the respondents indicated a preference for guided interpretation to non-guided interpretation, respectively (Table 2). The visitors who completed both the guided and the non-guided interpretation indicated that their preferred type of interpretation was guided interpretation. Secondly, 39\% of the respondents indicated that they believe guided interpretation to be more educational, whilst $22 \%$ of the respondents preferring guided interpretation attributed their preference to enjoying the personal aspect of having a guide (Table 3). A respondent from the non-guided Elephant Hall interpretation attributed their preference of guided interpretation to it being 'more informative' and to their view
TABLE 1: Effectiveness scores measured on a 5-point Likert scale against the four goals of interpretation.

\begin{tabular}{lcc}
\hline Goal of interpretation & \multicolumn{2}{c}{ Average ranking } \\
\cline { 2 - 3 } & Non-guided & Guided \\
\hline Visitor satisfaction & 4.09 & 4.49 \\
Knowledge gain & 3.68 & 3.63 \\
Attitude change & 4.29 & 4.31 \\
Intent to change behaviour & 3.73 & 3.78 \\
\hline Combined goals & $\mathbf{3 . 9 5}$ & $\mathbf{4 . 0 5}$ \\
\hline
\end{tabular}

TABLE 2: Preferred interpretation type.

\begin{tabular}{lcc}
\hline Respondents' interpretive preference & \multicolumn{2}{c}{ Percentage of respondents } \\
\cline { 2 - 3 } & Non-guided & Guided \\
\hline Non-guided & 17 & 13 \\
Guided & 83 & 87 \\
\hline
\end{tabular}

TABLE 3: Reasons for the preference of guided interpretation.

\begin{tabular}{lc}
\hline $\begin{array}{l}\text { Reasons for preference of guided } \\
\text { interpretation }\end{array}$ & $\begin{array}{c}\text { Percentage of respondents who indicated } \\
\text { a preference for guided interpretation }\end{array}$ \\
\hline More educational & 39 \\
More personal & 22 \\
More enjoyable & 9 \\
Prefer to listen rather than to read & 8 \\
Ask questions & 8 \\
Enthusiasm of the guide & 7 \\
Guided tours are more interactive & 7 \\
\hline
\end{tabular}

that guided interpretation requires 'less effort in receiving information'.

Visitors preferring non-guided interpretation stated that freedom $(50 \%)$ and reduced costs $(18 \%)$ were the most important reasons for respondents to prefer non-guided interpretation.

\section{Conclusion}

Increased tourism and the growing pressure on tourist sites and the environment have called for national parks and conservation areas to recognise the need for appropriate visitor management and interpretation. The aim of the research reported in this article was to utilise visitor perceptions to determine whether guided or non-guided interpretation is most effective in reaching the goals of interpretation. It was found that only marginal differences in the effectiveness between guided and non-guided interpretation exist. Although visitor satisfaction levels were higher in guided interpretation, the other three goals of interpretation, namely knowledge gain, attitude change and intent to change behaviour were only marginally different. The research has added depth of understanding to the general agreement amongst many authors that guided or personal forms of interpretation are the most effective, provided they are well planned and implemented (Armstrong \& Weiler 2002; Beaumont 2001; Brody et al. 2002; Ham 1992; Hughes \& Morrison-Saunders 2005; Luck 2003; Tubb 2003). This study provides valuable evidence that the effectiveness of interpretation can be measured through ascertaining visitor perceptions in relation to the four goals of interpretation. Interpretive planners should redesign both guided and 
non-guided interpretation programmes within the Kruger National Park to be more effective in terms of all four goals of interpretation. Interpretation should be seen as being vital to the conservation and preservation of natural areas as it aims to change visitors' attitudes and behaviours towards creating more environmentally responsible tourists that will ensure the long-term viability and sustainability of natural areas.

\section{Acknowledgements Competing interests}

The authors declare that they have no financial or personal relationships that may have inappropriately influenced them in writing this article.

\section{Authors' contributions}

M.R. (University of Portsmouth) conducted the research as part of his Masters dissertation in Ecotourism and co-authored the article. K.M. (University of South Africa) supervised the academic research and co-authored the article, whilst V.E. (University of Reading) was the supervisor of the academic research.

\section{References}

Aldridge, D., 1973, 'Upgrading park interpretation and communication with the public', in IUCN (ed.), Second World Conference on National Parks, Yellowstone and Grand Teton, USA, 18-27 September 1972.

Armstrong, E. \& Weiler, B., 2002, 'Getting the message across: An analysis of messages delivered by tour operators in protected areas', Journal of Ecotourism 1(2\&3), delivered by tour operators in protected areas', Journal
104-121. http://dx.doi.org/10.1080/14724040208668118

Ballantyne, R., Packer, J., Hughes, K. \& Dierking, L., 2007, 'Conservation learning in wildlife tourism settings: Lessons from research in zoos and aquariums', Environmental Education Research 13(3), 363-383. http://dx.doi.org/10.1080/ 13504620701430604

Beaumont, N., 2001, 'Ecotourism and the conservation ethic: Recruiting the uninitiated or preaching to the converted?', Journal of Sustainable Tourism 9(4), 317-341. http://dx.doi.org/10.1080/09669580108667405

Beck, L. \& Cable, T., 1998, Interpretation for the 21st century, Sagemore Publishing, Champaign.

Beckmann, E.A., 1991, 'Environmental interpretation for education and management in Australian national parks and other protected areas', $\mathrm{PhD}$ thesis, Department of Ecosystem Management, University of New England.

Bramwell, B. \& Lane, B., 1993, 'Interpretation and sustainable tourism: The potential and pitfalls', Journal of Sustainable Tourism 1(2), 71-80.

Brody, M., Tomkiewicz, W. \& Graves, J., 2002, 'Park visitors' understandings, values and beliefs related to their experience at Midway Geyser Basin, Yellowstone National Park, USA', International Journal of Science Education 24(11), 1119-1141. http:// dx.doi.org/10.1080/09500690210134820

Brown, P.J., McCool, S.F. \& Manfredo, M.J., 1987, 'Evolving concepts and tools for recreation user management in wilderness: A state-of-knowledge review', in R.C. Lucas (ed.), Proceedings of National wilderness research conference: Issues, stateof-knowledge, future directions, US Department of Agriculture, Forest Service, Intermountain Research Station, Ogden.

Buckley, R. \& Pannell, J., 1990, 'Environmental impacts of tourism and recreation in national parks and conservation reserves', Journal of Tourism Studies 1(1), 24-32.

Forestry Tasmania, 1994, Guided nature-based tourism in Tasmania's forests: Trends, constraints and implications, Forestry Tasmania, Hobart.

Gunderson, K., Barns, C.V., Hendricks, W.W. \& McAvoy, L.H., 2000, Wilderness education: An updated review of the literature and new directions for research education: An updated review of the literature and new directions for research Research Station, Ogden.

Ham, S., 1992, Environmental interpretation: A practical guide for people with big ideas and small budgets, North American Press, Golden.

Ham, S. \& Krumpe, E., 1995, 'How can site-based interpretation be used to change behaviors and contribute to biodiversity and ecosystem conservation in Central America?', paper presented at Academy for Educational Development (GreenCom Project), Technical Advisory Group Meeting, 16 October.

Ham, S. \& Weiler, B., 2000, Profile of tourists in the Panama Canal watershed protected areas: Final research report, Academy for Educational Development and GreenCOM Project, Washington, DC.

Ham, S., Housego, A. \& Weiler, B., 2005, Tasmanian thematic interpretation planning manual, Tourism Tasmania, Hobart.
Herbst, R.L., 1979, 'Introduction', Trends 16(1), 2.

Higham, J. \& Carr, A., 2002, 'Ecotourism visitor experiences in Aotearoa/New Zealand: Challenging the environmental values of visitors in pursuit of pro-environmental behaviour', Journal of Sustainable Tourism 10(4), 277-294. http://dx.doi. org/10.1080/09669580208667168

Hjalager, A., 1996, 'Tourism and the environment: The innovation connection', Journal of Sustainable Tourism 4(4), 201-218. http://dx.doi.org/10.1080/09669589608667268

Hu, W. \& Wall, G., 2012, 'Interpretation guiding and sustainable development: A framework', Tourism Management Perspectives 4, 80-85. http://dx.doi.org/10.1016/ j.tmp.2012.05.003

Hughes, K., 1991, 'Tourist satisfaction: A guided cultural tour in North Queensland', Australian Psychologist 26(3), 161-171. http://dx.doi.org/10.1080/00050069108 257243

Hughes, M. \& Morrison-Saunders, A., 2005, 'International activity participation, and environmental attitudes of visitors to Penguin Island: Western Australia', Society of Natural Resources 18, 611-624. http://dx.doi.org/10.1080/08941920590959587

Iozzi, L.A., 1989, 'What research says to the educator - Part one: Environmental education and the effective domain', Journal of Environmental Education 20(3), 3-9. http://dx.doi.org/10.1080/00958964.1989.9942782

Knudson, D., Cable, T. \& Beck, L., 1995, Evaluation: Interpretation of cultural and natural resources, Venture Publishing, State College. PMCid:PMC40522

Kohl, J., 2004, 'Putting environmental interpretation to work for conservation in a park setting: Conceptualizing principal conservation strategies', Applied Environmental Education and Communication 4, 1-19.

Krippendorf, J., 1987, The holiday makers, Heinemann, London.

Kuo, I.L., 2002, 'The effectiveness of environmental interpretation at resourcesensitive tourism destinations', International Journal of Tourism Research 4, 87101. http://dx.doi.org/10.1002/jtr.362

Larsen, D. (ed.), 2003, Meaningful interpretation - How to connect hearts and minds to places, objects and other resources, U.S. National Park Service, Fort Washington.

Lee, T. \& Balchin, N., 1995, 'Learning and attitude change at British Nuclear Fuel's Sellafield visitors centre', Journal of Environmental Psychology 15, 283-298. http://dx.doi.org/10.1006/jevp.1995.0025

Lewis, W., 1980, Interpreting for park visitors, Eastern Acorn Press, Philadelphia.

Lubbe, B.A., 2003, Tourism management in South Africa, Pearson Education, Cape Town.

Luck, M., 2003, 'Education on Marine Mamma tours as agent for conservation - But do tourists want to be educated?', Ocean \& Coastal Management 46(9), 943-956. do tourists want to be educated?', Ocean \& Coastal
http://dx.doi.org/10.1016/S0964-5691(03)00071-1

Mallick, S.A. \& Driessen, M.M., 2003, 'Feeding of wildlife: How effective are the "Keep Wildlife Wild" signs in Tasmania's National Parks?', Ecological Management and Restoration 4(3), 199-204. http://dx.doi.org/10.1046/j.1442-8903.2003.00157.x

Marion, J.L. \& Farrell, T.A., 1998, 'Managing ecotourism visitation in protected areas', in K. Lindberg, M.E. Wood \& D. Engeldrum (eds.), Ecotourism: A guide for planners and managers, vol. 2, pp. 155-181, The Ecotourism Society, Washington, DC

McArthur, S. (ed.), 1998, Introducing the undercapitalised world of interpretation, vol. 2, The Ecotourism Society, Washington, DC. PMid:10451319

McDonough, M.H., 1986, 'Evaluation: The interpreter's dilemma', in G.E. Machlis (ed.), Interpretive views: Opinions on evaluating interpretation in the National (ed.), Interpretive views: Opinions on evaluating interpretation in the National
Parks Service, pp. 99-105, National Parks Conservation Association, Washington, Parks Service, pp. 99-105,

McGehee, N.G. \& Santos, C.A., 2005, 'Social change, discourse and volunteer tourism', Annals of Tourism Research 32(3), 760-779. http://dx.doi.org/10.1016/j.annals. 2004.12.002

Moscardo, G., 1996, 'Mindful visitors - Heritage and tourism', Annals of Tourism Research 23(2), 376-397. http://dx.doi.org/10.1016/0160-7383(95)00068-2

Moscardo, G., 1998, 'Interpretation and sustainable tourism: Functions, examples and principles', Journal of Tourism Studies 9(1), 2-13.

Moscardo, G., Ballantyne, R. \& Hughes, K., 2006, Interpretive signs and exhibits Principles in practice, Fulcrum Books, Golden. PMCid:PMC1600016

Munro, J.K., Morrison-Saunders, A. \& Hughes, M., 2008, 'Environmental interpretation evaluation in natural areas', Journal of Ecotourism 7(1), 1-14. http://dx.doi. org/10.2167/joe137.0

Novey, L.T. \& Hall, T.E., 2007, 'The effect of audio tours on learning and social interaction: An evaluation at Carlsbad Caverns National Park', Science Education 91(2), 201-221. http://dx.doi.org/10.1002/sce.20184

Orams, M.B., 1996, 'Using interpretation to manage nature-based tourism', Journal of Sustainable Tourism 4(2), 81-94. http://dx.doi.org/10.1080/09669589608667260

Orams, M.B., 1997, 'The effectiveness of environmental education: Can we turn tourists into "greenies"?', Progress in Tourism and Hospitality Research 3(4), 295-306. http:// dx.doi.org/10.1002/(SICI)1099-1603(199712)3:4<295::AID-PTH85>3.0.CO;2-D

O'Riordan, T., Shadrake, A. \& Wood, C., 1989, 'Interpretation, participation and national park planning', in D. Uzzell (ed.), Heritage interpretation - The natura and built environment, pp. 179-189, Belhaven, London. PMCid:PMC1385425

Pastorelli, J., 2003, Enriching the experience: An interpretive approach to tour guiding, Hospitality Press, Frenchs Forest.

Pearce, P. \& Moscardo, G., 1998, 'The role of interpretation in influencing visitor satisfaction: A rainforest case study', in W. Faulkner, C. Tidswell, \& D. Weaver, (eds.), Progress in tourism and hospitality research, Part 1, Proceedings of the 8th Australian Tourism and Hospitality Research Conference, Gold Coast, 11-14 February, pp. 309-319, Bureau of Tourism Research, Canberra.

Phillips, A., 1989, 'Interpreting the countryside and the natural environment', in D. Uzzell (ed.) Heritage interpretation - The natural and built environment, pp. 121131, Belhaven, London. 
Regnier, K., Gross, M. \& Zimmerman, R., 1994, Techniques for programs and presentations, 3rd edn., UW-SP Foundation Press, Stevens Point. PMCid:PMC395234

Russell, C.L. \& Hodson, D., 2002, 'Whale watching as critical science education?', Canadian Journal of Science, Mathematics and Technology Education 2(4), 485504. http://dx.doi.org/10.1080/14926150209556537

Ryan, C., Hughes, K.C. \& Hirgwin, S., 2000, 'The gaze, spectacle and ecotourism', Annals of Tourism Research 27(1), 148-163. http://dx.doi.org/10.1016/S01607383(99)00061-4

Schänzel, H.A. \& McIntosh, A.J., 2000, 'An insight into the personal and emotive contex of wildlife viewing at the Penguin Place, Otago Peninsula, New Zealand', Journal of Sustainable Tourism 8(1), 36-52. http://dx.doi.org/10.1080/09669580008667348

Shackley, M., 1998, Visitor management - Case studies from World Heritage sites, Butterworth-Heinemann, Oxford. PMCid:PMC1364099

Sharpe, G. (ed.), 1982, An overview of interpretation, 2nd edn., John Wiley \& Sons, New York.

Stewart, E.J., Hayward, B.M. \& Devlin, P.J., 1998, 'The "place" of interpretation: A new approach to the evolution of interpretation', Tourism Management 19(3), 257-266. http://dx.doi.org/10.1016/S0261-5177(98)00015-6

Tilden, J., 1977, Interpreting our heritage: Principles and practices for visitors in parks, museums and historic places, 3rd edn., University of North Carolina Press, Chape Hill. PMid: 832384

Tisdell, C. \& Wilson, C., 2001, 'Wildlife-based tourism and increased support for nature conservation financially and otherwise: Evidence from sea turtle ecotourism at Mon Repos', Tourism Economics 7(3), 233-249. http://dx.doi. ecotourism at Mon Repos', Tourism
org/10.5367/000000001101297847

Townsend, C., 2003, 'Marine ecotourism through education: A case study of divers in the British Virgin Islands', in B. Garrod \& J.C. Wilson (eds.), Marine ecotourism Issues and experiences, pp. 138-154, Channel View Publications, Clevedon.
Tubb, K., 2003, 'An evaluation of the effectiveness of interpretation within Dartmoor National Park in researching the goals of sustainable tourism development', Journal of Nustainable Tourism 11(6), 476-498. http://dx.doi.org/10.1080/09669580308667217
Sulional

Uzzell, D., 1998, 'Strategic considerations and practical approaches to the evaluation of heritage interpretation', in D. Uzzell \& R. Ballantyne (eds.), Contemporary issues in heritage and environmental interpretation: Problems and prospects, pp. 185202, Stationery Office, London.

Van der Merwe, P. \& Saayman, M., 2008, 'Travel motivations of tourists visiting the Kruger National Park', Koedoe 50(1), 154-159. http://dx.doi.org/10.4102/koedoe. v50i1.140

Vaske, J.J., Donnelly, M.P. \& Whittaker, D., 2000, 'Tourism, national parks and impact management', in R.W. Butler \& S.W. Boyd (eds.), Tourism and national parks, pp. 203-222, Wiley, Chichester.

Ward, C. \& Wilkinson, A., 2006, Personal interpretation - A field guide for success, Fulcrum Books, Golden.

Wearing, S., Archer, D., Moscardo, G. \& Schweinsberg, S., 2007, Best practice interpretation research for sustainable tourism: Framework for a new research agenda, Sustainable Tourism CRC, Queensland.

Weaver, D., 2000, 'Tourism and national parks in ecologically vulnerable areas', in R.W. Butler \& S.W. Boyd (eds.), Tourism and national parks, pp. 107-124, Wiley, Chichester. PMid:11011800

Weiler, B. \& Smith, L., 2009, 'Does interpretation lead to greater outcomes? An assessment of the impacts of multiple layers of interpretation in a zoo context' Journal of Sustainable Tourism 17(1), 91-105. http://dx.doi.org/10.1080/ 09669580802359319

World Tourism Organisation, 1992, Guidelines: Development of national parks and protected areas for tourism, WTO, Madrid.

World Tourism Organisation, 1995, What tourism managers need to know: A practical guide to the development and use of indicators of sustainable tourism, WTO, Madrid. 